\title{
INTERNATIONAL MECHANISMS FOR PROSECUTING ISIL MEMBERS FOR THEIR CRIME OF GENOCIDE AGAINST YAZIDIS PEOPLE IN SINJAR, IRAQ - 2014 \\ INTERNATIONAL CRIMINAL COURT (ICC) AS A CASE STUDY
}

\author{
SAMAN OMAR \\ Independent Security Studies Researcher
}

(Accepted for Publication: 10 January, 2021)

\begin{abstract}
On August 3, 2014, the terrorist organization Islamic State in Iraq and the Levant (ISIL), also known as Da'esh or most recently shortened to Islamic State (IS) attacked Sinjar in Northern Iraq within the Nineveh province. The region was home to about 400,000 Yazidis as well as other religious minorities. More than two million people have caused serious human rights violations in Nineveh province.

ISIL captured Sinjar and the surrounding villages within a few hours on that fateful morning. The Yazidis were specifically targeted by ISIL members and were subjected to some of its worst atrocities including but not limited to executions, sexual slavery, abduction, forced conversion, imprisonment and torture.

At the request of the Iraqi government, the United States began conducting air strikes and airdropping humanitarian aid on August 8, 2014. Between August 9 and 13, Kurdish forces opened a safe corridor, allowing most of the surviving Yazidis to flee through Syria into the Kurdistan region of Iraq.

The Rome Statute of the International Criminal Court (ICC) expressly incorporates the court has jurisdiction in accordance with this Statute with respect to the crimes of (a) Genocide; (b) Crimes against humanity; (c)War crimes; (d) The crime of aggression. These are elaborated on in Articles 5 and genocide specifically in Article 6.

This study aims to find out whether such heinous international crimes committed by IS against the Yazidi people in Sinjar, Iraq during 2014-2017 can be placed under the jurisdiction of the ICC in accordance with its governing document, the Rome Statute.

The study is illustrative and uses a content analysis approach to answer research questions. The researcher analyzed the existing literature as well as the ICC legal documents to interpret and determine the jurisdiction of the ICC regarding the Yazidi genocide in Iraq to ultimately recommend and demand reform at the end of the study.
\end{abstract}

KEYWORDS: Genocide - Members - Yazıdıs

\section{INTRODUCTİON}

\subsection{Background of the study}

O n August 3, 2014, ISIL attacked Sinjar and the area around Sinjar mountain, home to hundreds of thousands of Yazidis, the second largest ethnic and religious minority in Iraq. ISIL captured more than 10,000 Yazidis and systematically separated women and men, murdering the men and selling women and children into slavery. The horrific crime has been recognized as genocide by international organizations and the global community.

ISIL attacked Sinjar in northern Iraq, as part of their campaign to eradicate the Yazidi people and "purify" the region of non-Islamic influences. ISIL militants offered the Yazidi villagers a choice: convert to Islam or be executed on the spot. To young girls and women a third path was presented: slavery.

The Rome Statute of the International Criminal Court (ICC) expressly incorporates that the Court has jurisdiction in accordance with this Statute with respect to the crimes (a) Genocide; (b) Crimes against humanity; (c) War crimes; (d) The crime of aggression. These are elaborated on in Article 5, and genocide is specified under Article 6.

At the request of the Iraqi government, the United States began conducting air strikes and air-dropping humanitarian aid on August 8. Between August 9 and 13, Kurdish forces 
opened a safe corridor, allowing most of the surviving Yazidis to flee through Syria into the Kurdistan region of Iraq.

\subsection{Literature Review}

It is understood that brutal executions and merciless abductions were carried out in Sinjar by ISIL. The religious minority of Yazidis were killed and abducted systematically. The study outlined that the militants detained the Yazidi women and children in the area of Sinjar without providing basic necessities like food and water. Many people detained dies of starvation and inhumane conditions. The inhumane abduction and killing continued for days and the Yazidis were seized without any support and help from neighboring countries (Buffon and Allison ,2016).

Current studies paint a picture of the kidnappings, executions and consequent displacement of the Yazidi people as massive. The study collected data via household surveys, the results of which are affirmed by other studies in that the actual number of deaths during and after the genocide is still unknown, with many Yazidis still missing (Cetorelli, Sasson, Shabila, and Burnham, 2017).

Research by Ahram outlined that the Yazidi women in Sinjar were captured, abducted, and forced into prostitution by the ISIL militants. The Yazidi males were killed but women were kept to be forced as sex workers. The study outlined that the Yazidi women and children were kept alive to be trafficked to other countries where they also worked as sex slaves. This genocide was executed on an enormous scale and was justified based on a distorted interpretation of the Koran. These were crimes committed against humanity; the persecution, killings and enslavement being legitimized in the name of Islam by the extremist group (Ahram, 2015).

Nicolaus and Yuce further added that the these violatins of international law go well beyond genocide, and also include specifically crimes against humanity. The ISIL militants also prosecuted brutal and inhumane behavior against women and children. They killed the Yazidi men and captured their women and children. Human trafficking and sex slavery are among these specific crimes against humanity (Nicolaus and Yuce, 2017).

The contribution of this research to existing literatüre will support the international community to better understand the legal framework pertaining to IS' crimes, and will better able the ICC to prosecute such cases.

\subsection{Statement of Problem}

ISIL's crimes against the Yazidis constitute a case of genocide, defined by the 1948 Convention on the Prevention and Punishment of the Crime of Genocide, also included in the Rome Statue of the ICC in 1998. Genocide is defined as, "Acts committed with intent to destroy, in whole or in part, a national, ethnical, racial or religious group." ISIL had openly proclaimed, in its English-language magazine, Dabiq, its intent to destroy the "Pagan" Yazidi minority through killing, enslavement, and forced conversion

\subsection{The Aim of the Study}

The aim of this study is to explore the international mechanism for prosecuting ISIL members for their crimes of genocide against Yazidies in Sinjar, Iraq in 2014.

\subsection{Research Question}

1. What jurisdiction does the ICC have regarding holding ISIL members accountable for their crimes of genocide against Yazidis in Sinjar, Iraq in 2014?

\subsection{Significance of the Study}

The study addresses a vital aspect to Yazidis' retribution process by acknowledging the significance of documenting the extent of ISIL's genocidal crimes, and further advocating to support accountability efforts in national and international courts and tribunals.

\subsection{Limitation of the Study}

The study is a qualitative research and will not include the opinions of the large population. The study focused solely on the time period of $2014-2017$ in Sinjar and will not include empirical methods for collecting and analyzing data.

\subsection{Methodology}

The study is illustrative and uses a content analysis approach to answer research questions. The researcher analyzed the existing literature as well as the ICC legal documents to analyze the jurisdiction of the ICC regarding genocide in general and then specifically with Sinjar in Iraq to conclusively demand reform. 


\section{INTERNATIONAL CRIMINAL LAW AND THE JURISDICTION OF INTERNATIONAL CRIMINAL COURT}

\subsection{The term of Genocide}

Genocide is a distinct concept. It became a part of international law (IL) in mid-1940s at the end of the World War II (WWII). Genocide focuses on killing people by destruction of groups - it means that killing individuals who are part of a particular group. The act of genocide can be prosecuted on the basis of: (a) killing members of the group; (b) causing serious bodily or mental harm to members of the group; (c) deliberately inflicting on the group conditions of life calculated to bring about its physical destruction in whole or in part; (d) imposing measures intended to prevent births within the group; and (e) forcibly transferring children of the group to another group. Contrarily, Raphael Lemkin introduced genocide killing groups (Ford, 2006).

Another legal definition of genocide, as provided in Article 4 (2) of the International Criminal Tirbunal for the former Yugoslavia (ICTY) Statute, and Article 2 (2) of the ICTR Statute, is "any of the acts in article (2) of Convention on the Prevention and Punishment of the Crime of Genocide 1949 (CPPCG) committed with intent to destroy, in whole or in part, a national, ethnical, racial or religious group (Marchuk, 2014).

From the above definitions, genocide can be defined as "the intent or attempt to destroy, in whole or in part, a nation, ethnic or religious group, in accordance with well-planned and coordinated plans and procedures. This destruction encompasses all the basic foundations of the life of these national groups, and it was established by the international community that what happened to the Yazidi community was, in fact, genocide.

\subsection{History of Genocide}

The concept of genocide like most legal concepts evolved over the period of time. The previous crime evolved and developed out of the body of rules that regulate the use of force during conflict and war in late $19^{\text {th }}$ and early $20^{\text {th }}$ century. Thus, it evolved with the evolution of laws governing armed conflicts, and it is now recognized as a specified crime. However, the Geneva Conference of 1968 made it clear that genocide is not limited to armed conflict, just that it is more common amidst an armed conflict. (Ford, 2006).

The term was introduced in 1948 and was defined as deliberate and systematic destruction of a particular religious, race, ethnicity and/or national group. It was defined in Article 2 of Convention on the Prevention and Punishment of the Crime of Genocide. According to Jones, if a dominant group has little in common with that of the marginalized group, it is easy for the dominant group to define the other as subhuman (Jones, 2016). Jones continues, "The difficulty, as pointed out in an early study by Chalk and Jonassohn, is that such historical records exist as ambiguous and undependable. While history today is generally written with some fealty to 'objective' facts, most previous accounts aimed rather to praise the writer's patron (normally the leader) and to emphasize the superiority of one's own gods and religious beliefs. It is then argued that there are differences among human beings, most emphasized in terms of religion, language, manners, customs, and so on whereas, others can be minority (Chalk and Jonassohn, 1990).

Prior to 1949, literatüre supports that genocide had already happened against the indigenous people on a global scale. It is also argued that not only genocide but gendercide had also been executed against these indigenous people meaning that crimes committed against individuals was often based on their gender. Gendercide refers to killing only the males and letting females and children to be part of the conquering groups. Ancient gendercides have also been popular where Midianites were destructed. The literature suggests that there is no exact count for the number of Midianites killed but 32,000 girls survived that were taken by the conquering group. Furthermore, in fourth century, racial genocide was executed against ancient Chinese that killed about 200,000 Jie people, which had high bridged nose and bushy hair. Similarly, the Mongol Empire's army in $13^{\text {th }}$ century executed genocide led by Genghis Khan. They also aimed to destroy whole nation. From 1490-1914, Congo, French conquering Algeria, German, Zulu Kingdom, Americas including Argentina, Mexico, Haiti, Canada and Asia including Afghanistan, East India Company rule of Subcontinent, Dzungar genocide, Ottoman Empire, Japanese Conquest, Russia, Vietnam, Europe, and the British Empire all experienced massacre and genocide and crimes against humanity. Historically, it is been 
observed that the crimes against humanity and the genocide existed for long but it is now that the phenomenon is under consideration of the international law and court of justice. Unfortunately, this dark phenomenon still exists today as we see with the Yazidi community among others (Meierhenrich, 2014).

Here are two elements of the special intent requirements of genocide:

1. The act or acts must target a national, ethnical, racial or religious group;

2 . The act or acts must seek to destroy all or part of that group (Stromseth, 2011).

\subsection{Jurisdiction of International Criminal Court}

The development of international criminal law (ICL) during the 21st century will arose primarily out of the jurisprudence of the permanent International Criminal Court located in The Hague. For three and a half years, a majority of the world's governments sent legal experts and diplomats to several multi-week sessions annually to negotiate the provisions of the statute for the ICC. They agreed to go to Rome to finish the statute in the summer of 1998 and, after five intensive weeks of negotiations, a final text emerged on 17 July. The Rome Statute of the ICC was adopted by an overwhelming majority of votes when 120 governments approved the final text, 21 abstained, and seven vetoed, including the United States, the People's Republic of China, and Israel.

The Court has four organs: the judicial chambers, the presidency, the prosecutor, and the registry. There are 18 judges elected by majority vote of the Assembly of States Parties for terms of nine years (except for some who had lesser terms in the beginning of the Court). The ICC began functioning on 1 July 2002 to prosecute Thomas Lubanga who was convicted of snatching children from the street and indoctrinating them into trained killers for armed conflict in the Democratic Republic of the Congo (DRC). The subject matter jurisdiction of the Court is set forth in Articles 5 through 8 of the Rome Statute. It consists of the atrocity crimes described earlier: Genocide, Crimes Against Humanity, War crimes and Aggression (Dörmann, 2003). Article 13 of the Rome Statute issued that the ICC has many jurisdictions in terms of exercising and implementing new laws and policies as referred by the UN Security Council as described in chapter VII of the UN Charter. Similarly, the acts of aggression can also be referred to the ICC for prosecution by the Security Council (Stromseth, 2011).

Security Council deferral of investigation or prosecution Article 16 of the Rome Statute recognizes the Security Council's power to adopt an enforcement resolution under Chapter VII of the UN Charter that requests that an investigation or prosecution of a case or an overall situation not be commenced or continued for a period of 12 months, a period that can be renewed in the same manner (Arsanjani,1999). The origin of this provision arises from the effort by some governments, particularly the United States, to require that all situations be referred to the Court either by the Security Council or by a state party provided the Council approved the referral if the situation pertained to a matter already before the Council. When the Council oversight role was eliminated during the negotiations and the prosecutor gained the power to initiate investigations with Pre-Trial Chamber approval (Hwang, 1998).

The member states are obliged to follow and comply with the policies and laws that are designed and implemented by the ICC. The ICC plays an important role when the domestic court fails to exercise justice. Large-scale violence and crimes that universally recognized as especially heinous and threats to global peace and security has always been the focus of court's investigations ( Newton,2001).

The focus of these courts is on the free and fair trials and delivery of justice. Hence, they have been successful in eliminating crimes and prosecuting criminals. Thus, the jurisdiction of the ICC was established in 2002. The ICC only has jurisdiction over genocide, crimes against humanity, crimes of aggression, and war crimes when the primary countries are unable or unwilling to investigate or prosecute ( Llorens, 1998 ). 


\section{ISIL AND CRIME OF GENOCIDE AGAINST YAZIDİS İN SİNJAR, IRAQ 2014}

\subsection{What happened to Yazidis in Sinjar?}

ISIL's campaign to "purify" the territory across northern Iraq and Syria by eliminating non-Islamic influences carried a devastating price for the Yazidi population, who were labelled as "infidels" by the group. In early August 2014, ISIL launched its attack on Sinjar from Mosul and Tel Afar in Iraq, and AlShaddadi and the Tel Hamis region (Hasakah) in Syria. According to the UN-mandated Commission of Inquiry on Syria (COI), the attack on Sinjar city and surrounding villages was organized and orchestrated in a manner that seized control of the area from all directions and targeted the area's main roads and escape routes. Fleeing for their lives, somewhere between 35,000 and 50,000 members of the Yazidi community (many of them women and children) took refuge in nine locations on Mount Sinjar. In addition, approximately 130,000 Yazidis fled to the towns of Duhok or Erbil in Northern Iraqi Kurdistan. Those who made it to the mountain were right away faced with a deadly reality. Mount Sinjar, a 100-Kilometer-long arid mountain, was destined for humanitarian disaster, with thousands of civilians stranded without water, food, shade, or medical supplies. Reports of Yazidis eating leaves to survive surfaced, while hundreds died of thirst in temperatures sometimes exceeding 50 degrees Celsius. In the first week of August 2014, local authorities reported that at least 500 Yazidis had been killed in such conditions and that many more had received direct threats, either from advancing ISIL fighters or from members of nearby Sunni communities allied with them.

The Sinjar attack marked the start of a highly systematized and brutal campaign to erase the Yazidi identity. Men were forced to choose between conversion to Islam or death. Girls, women and their children were abducted and held captive, before being bartered, sold and exchanged into slavery. Boys as young as seven were sent to recruitment camps in Syria where they were indoctrinated with ISIL ideology and forced to undergo military training. At the core of ISIL's strategy lies the taking of Yazidi women and their children as sabaya (prisoners of war), which paved the way for systematic enslavement and sexual violence on a horrifying scale (Van Schaack, 2019).
It was quickly apparent that the horrors being visited upon captured Yazidis were occurring systematically across ISIL-controlled territory in Syria and Iraq. In this report, the Independent International Commission of Inquiry on the Syrian Arab Republic examines the crimes ISIL is committing against Yazidis, thousands of whom are now held in Syria. While the report analyzes a range of international crimes, it specifically seeks to determine whether ISIS has committed the crime of genocide.

There is little doubt that ISIL has repeatedly committed actions that are criminal under the Rome Statute. It has been systematically murdering, exterminating, enslaving, forcibly transporting, raping, committing other sexually violent acts, persecuting groups based on their religion and ethnicity, and committing "inhumane acts of a similar character intentionally causing great suffering, or serious injury to body or to mental or physical health." The U.N. Assistance Mission for Iraq and the Office of the U.N. High Commissioner for Human Rights released a report on ISIL's actions against civilians, specifically actions against women and children from July 6, 2014, to September 10, 2014. The report described how ISIL forced children as young as twelve or thirteen years old into service by donating their blood to treat wounded ISIL soldiers, patrolling ISIL controlled towns, and manning ISIL checkpoints.

ISIL has also used children as shields in skirmishes with Iraqi and other resistance forces. The report called on the International Criminal Court to launch an investigation into these crimes. Ever since ISIL first started operating in Iraq (initially as al-Qaeda), it targeted both civilians and military personnel. Most ISIS fighters are members of the Sunni Muslim sect, and at first ISIL primarily went after Shi'ite targets, Shi'ites being the majority in Iraq as a whole but a minority in ISIL-dominated Northern Iraq. In 2014, however, ISIL began targeting other ethnic minorities including Christians, Yazidis, Shabak, Shi'ite Turkmen, and those Sunni Muslims who disagreed with ISIL's religious philosophy and actions (Larkin, 2018).

Between June 2014 and December 2017, ISIL captured, controlled and operated with impunity over large swathes of territory in Iraq, committing grave abuses of international human rights law, international criminal law and 
international humanitarian law — acts that amount to war crimes, crimes against humanity and genocide. The subsequent liberation of large areas of Iraq from the control of ISIL has exposed the magnitude of the crimes inflicted on the inhabitants of these territories. Witness testimony has revealed a plethora of abuses committed against the populations under ISIL control, including executions, torture, amputations, ethno-sectarian attacks, rape and sexual slavery imposed on women and girls. Thousands of children have become victims, witnesses and forced perpetrators of ISIL atrocities. To date, more than 200 mass graves containing the remains of thousands of men, women and children have been discovered in areas formerly controlled by ISIL. These largescale crime scenes are sites of harrowing human loss, profound suffering and shocking cruelty. As ISIL has been driven from its strongholds in Iraq, the international community has emphasized the crucial importance of holding senior members accountable for the crimes they have committed, on the basis of objective, evidence, thorough investigation and analysis. It has also recognized that the detailed and factual presentation of ISIL atrocities in fair and transparent criminal proceedings will be central to efforts aimed at undermining the ideological underpinnings of the ISIL movement, and thereby reducing the ability of its form of violent extremism to spread further. It is in this context that on 9 August 2017, the Government of Iraq called for the assistance of the international community in ensuring that members of ISIL were held accountable for their crimes in Iraq, including where they might amount to crimes against humanity (S/2017/710) (Tobjasz \& Bove, 2020).

The UN estimates that more than 3,100 Yazidis are still within ISIL captivity, including 1,452 women and girls (Kelly,2016).

In total, nearly 10,000 of the ethnic and religious minority were slaughtered or captured in a matter of days in early August 2014 when ISIL raged through Sinjar, according to a study published in PLOS Medicine. Yazidis were subject to the most brutal treatment by the jihadi fighters who regard them as "devil worshippers" for their belief in a peacock-shaped angel. Thousands were shot dead, burnt]ed alive and beheaded. Women and girls as young as 12 were taken as sex slaves. Many others were taken away from their mothers and made to work as servants. Despite the fact that ISIL is largely defeated in Iraq and its influence is waning in Syria, there are thought to be at least 3,000 Yazidi women and children still in their captivity (Bel Trew, 2018).

\subsection{ISIL and Crime of Genocide 3.2.1 Rome Statute}

According to the Rome Statute, the aim and objective of the ICC is to avoid the acts of the aforementioned crimes against humanity, war crimes and genocide. These crimes cannot remain unpunished or else they will continue to be promoted in future as well. Genocide, war crimes, crimes against humanity, and crimes of aggression are to be pursued and prosecuted. Hence, the ICC aims to prevent such crimes to promote peace and justice in the local, regional and global society. Ultimately, the purpose of establishing ICC is to ensure accountability for committing such crimes (Munivrana Konforta, \& Munivrana,2014)

The Rome Statute with Pre-Trial Chambers of the ICC fully justifies the prosecution of such extremist organizations including ISIL for committing crimes against humanity. It is also clearly mentioned that the level of the group and/or the organization will not be the criterion to judge whether the group can be prosecuted for committing such crimes or not. At the same, the Statute clearly mentioned that militant organizations such as ISIL can be openly prosecuted for systematically committing act of genocide and crime against humanity (Quigley, 2016).

\subsubsection{Criterion for Punishment}

The Pre-Trial Chamber specified certain criterion to charge any group or organization for the aforementioned crimes, and is encouraged in the Rome Statute to execute these groups and/or organizations:

1. The first criterion of a group to qualify for punishment is that the group has an identified hierarchy;

2. The capability of a group to conduct such crimes like genocide and/or crimes against humanity;

3. The group has attacked/occupied a territory where these crimes are committed;

4. The intentions of the group to conduct violence and inhumane criminal activities against the unarmed civilians intentionally;

5. The group has an intend to harm the civilian population; 
6. The group can be and is part of the larger group that is committing such crimes and qualifies above all criterions will be executed.

Hence, for any individual or group to be punished for committing crimes against humanity and crimes of international nature, it must have been convicted from the above mentioned criterion. ISIL executions against the Yazidi people can be questioned under such criterion that has been analyzed in the proceeeding chapter (Greco, 2007).

\section{ANALYSISS OF THE ROME STATUTE OF İCC AND CHARGING ISIL}

\subsection{Comparing Rome Statute and Sinjar}

Since the adoption of the Rome Statute in 1998, the ICC issued its first warrant in 2005 and the first trial was carried out in 2009 for systematic crimes against humanity and genocide performed in Rwanda and Yugoslavia. The systematic crimes in Rwanda and Yugoslavia were first to be broadcasted as systematic human destruction. Hence, global actors and audiences were eager for accountability and justice (Borg Cardona ,2013).

\begin{tabular}{ll}
\hline Rome Statute & Sinjar Case \\
\hline Killing & Yazidi men were killed brutally \\
\hline Serious mental and physical harm & $\begin{array}{l}\text { Yazidi women were sexually and physically tortured, } \\
\text { raped, and enslaved }\end{array}$ \\
\hline Deliberate conditions for physical destruction & Yazidi people captured and trapped were besieged \\
\hline Conditions for preventing birth & $\begin{array}{l}\text { Yazidi women were forced to abort their children as they } \\
\text { were forced to be sex slaves before ISIL, and Yazidi } \\
\text { men were separated from Yazidi women. }\end{array}$ \\
\hline Forced transfer of children & $\begin{array}{l}\text { Yazidi children were abducted forcefully and transported } \\
\text { to different locations, isolated from their community }\end{array}$ \\
\hline
\end{tabular}

From the above evidence and as discussed in previous chapters, it is clear that ISIL committed crimes that are labeled as genocide by Convention on the Prevention and Punishment of the Crime of Genocide of 1948 and Rome Statute of ICC. All of the pre-requisites were met in determining that ISIL did, inf act, commit these crimes. ISIL committed genocide to destroy in part or whole individual Yazidis and the greater Yazidi community. According to the Genocide Convention and the Rome Statute, the Yazidi community falls under the category of protected ethnic and religious group.

\subsection{Applications of the elements}

\subsubsection{Yazidi are an ethnic and religious group}

The first requirement for the ICC jurisdiction for genocide is to identify that Yazidi people as an ethnic and/or religious group. According to systematic study, Yazidi people are defined as an ethnic and religious group. An ethnic group in the Rome Statute is defined as a group having its own language, customs, and traditional attachment with the land and distinctive culture. These attributes allow the victims not only Yazidis to seek protection and execution of these mass killings and abductions. With that being said, it should be noted that Yazidis were mainly persecuted based on their religious affiliation rather than their ethnicity.

\subsubsection{Intent to destroy and manifest pattern}

For the genocidal crime, both mental and physical elements must be present. Under the Mens rea component, Article 30 of the ICC Rome statue has two components. It includes both specific intent and knowledge threshold. Both of these components contribute to differentiating genocide from other international crimes. The Mens rea cannot be suspected directly from direct evidence or proof. The criminal law assumes that the person is accountable for his actions and he knows the consequences of his crimes. Based on the evidence and proof, it can be considered that the proof of intent is inferred indirectly from the logical deductions.

The second component of knowledge can be referred to as the awareness about the consequences which may occur as a result of the perpetrator's actions on the defendant. For the crime of genocide, negligence is inappropriate. In the crime of genocide, the knowledge threshold for specific intent directly indicates an obligation for government, bureaucracy, organization, or logical planning against the protected group. The genocide crime is usually not committed by an individual on its own. Genocide can be done by having required knowledge which can be deduced from the 
nature of order given to a person without having full awareness about the crime (Scharf,1997). The specific intent defines whether the required intent is to destroy the ethnic group as a whole or individually. Behind the general intent, there is an intent which demands the need of action taken against a special targeted group (Lingaas, 2015).

During the preparation of the Genocide Convention, the United States had initially suggested a "plan to destroy" element, but later modified it to "widespread or systematic policy or practice." Due to the requisite immense scale of the crime, this wording was criticized as unnecessary and useless. However, Israel noted that "it is hard to conceive of genocide without it." The "plan" was suggested as acceptable in the consensus text but in a vigilant form.

On the other hand, the ICC Rome Statute clearly required a "manifest pattern" as an appropriate element for genocide. This prerequisite is deduced from the Genocide Convention's implied element of systemic pattern or a plan. To guarantee that manifest pattern meets the high standard of the specific intent "to destroy," the ICC Rome Statute needs that each of the actus rei support with this plan or "manifest pattern. It is done by making the manifest pattern a formal element. As the men's rea and acti rei components are considered by the court, so this is proven in perspective. On the application level, it is believed that proving knowledge is easy for a subordinate. The significance of a plan in committing genocide is crucial. To destroy the Yazidis, the manifest pattern was shown by the ISIL terrorists by displaying several thousands of Yazidi children, women, and men (Stahn, Olásolo, \& Gibson,2006).

\subsection{ISIL Committed Genocide}

The ISIL militants started the genocide of the Yazidi people in Sinjar on August 3, 2014. It is considered as genocide under the Rome State, Article (6) which is genocide by killing members of a group, in whole or in part. From that time until present day, ISIL terrorists have analytically targeted and killed the Yazidis (Clark,2001). It is done by considering them heretics, devil worshippers, and irreconcilable with their fanatical beliefs. They are considered as extremist and are being punished for their religious beliefs. The witnesses reported that the IS fighters initially tried to convince the villagers of the Yazidi to change their religion to Islam.
They allegedly spent five days to convince them to convert. When they were not convinced after these five days, ISIL members mercilessly captured Sinjar (Hawramy, 2019).

There were many reports of crimes and violence against the Yazidis done by ISIL. It included the systemic execution of Yazidi men and the selling of women and children. The reports also showed that there was knowledge about the Yazidi's ethnic groups and religions. They were also well aware of their culture and geographical locations. Five explicit acts that will independently form legal genocide are highlighted by the Rome Statute, and they are as follows:

- The assassination of the members of the targeted group

- Causing severe physical or mental harm to members of the group

- Deliberately imposing on the group conditions of life calculated to bring about its physical destruction in whole or in part

- Imposing procedures planned to prevent births within the group

- Forcibly transferring children of the group to another group as slaves or any other purpose

The crimes of ISIL were beyond inhumane. They intended to torture the Yazidis both physically and mentally. The women were raped and many Yazidi girls committed suicide from the fear of being sold or raped indefinitely. Starvation and the malnutrition was another important aspect of physical harm for the Yazidi people. They were forced out of their houses which resulted in their squatting in the mountains (Sebastian, 2015 ). Many Yazidi women were sold several times and were forced to perform the household works. They were also deprived of adequate food and water by their militant owners. Survivors who were able to escape from the ISIL captivity reported that they were beaten brutally and were often gang raped as well. They were punished if they tried to escape (Schmid 2015) The Yazidi women who were captivated as sex slaves and faced daily rapes with gradually led to many slow deaths (Sypher,, 2014).

Measures were taken by ISIL to stop the birth of new Yazidi children. Abortion of women was performed who were expecting children. A woman reported that a ISIL doctor sat on her stomach to kill the unborn baby. Young girls were raped frequently and pregnant women were 
given harmful pills. The degree of the sexual assault was severe which led to the deaths of many girls. Rape and sexual assault is arguably the worst inhuman act performed by the ISIL on Yazidis (Goldstone,2002). The torture of sexual slavery was bestowed upon those women who did not convert to Islam. On the contrary, those who converted to Islam were given as brides to the ISIL fighters.

The young children of the Yazidis were kidnapped and were trained to become the future Jahidis of the terrorist group. It was an effort to destroy the community on both ethnic and religious terms. It is considered as genocide as the children's future will be affected by the change and they are taught to become completely detached from their religion and ethnicity. The prohibition of the use of national language in private schools ensured that children are not being trained in their native tongue. The destruction or dispersion of documents and things that have artistic, religious, ethnic values, and historical significance is genocide which affects the future of individuals and of the group. It destroys the cultural and social values which should be transmitted to the next generations (Anderson,2016).

\subsection{Charging ISIL for genocide under the Rome Statute (ICC)}

Iraq and the Kurdish Regional Government (KRG) have the right and authority to prosecute ISIL under the ICC's Rome Statute for committing genocide, crimes against humanity and war crimes. The KRG and Iraq, according to the domestic enforcement by Article 6 of the Rome Statute, needs international assistance, not just financially but technically and professionally in order to prosecute ISIL for their violations of international law and in pursuit of justice for the Yazidi people.

The security council also has the right to prosecute ISIL members in acordance to the Rome Statute's Article 12(3) by Iraq representive at the UN to file a declaration with the registrar to give the prosecutor the right to exercise in the case of the Court. Article 13(b,c) and 16 of the Statute state that the UN Security Council has the right to refer the case and deferral of investigation or prosecution as described under chapter VII of the UN charter.

\section{CONCLUSION AND RECOMMENDATIONS}

\subsection{Conclusion}

ISIL systematically executed Yazidi people in Sinjar, Iraq on a massive scale, justifying it with their warped interpretation of Koranic verses. The militant group confidently committed crimes like: brutal execution, sex slavery, abduction, forced conversion, imprisonment and torture against Yazidi people. These crimes are considered as international crimes and crimes of genocide in accordance with Article 6 of the Rome Statute of the International Criminal Court.

The results of the study, supported by existing literatüre, found that the requirements of the crime of genocide were in fact met by ISIL, both materially and morally. It has been universally recognized by the international community as well as the ICC that the obligations of prevention and responsibility contained in the International Convention on the Prevention of Genocide and the Rome Statute must be invoked in this specific case with the Yazidis, as such atrocities and the failure to hold perpetrators accountable threatens the international peace and security. The individuals and groups committing these crimes must be prosecuted in order to promote peace and security in the Yazidi community, throughout the region, and around the World.

The findings of the study suggested that the ICC has no direct jurisdiction over ISIL, however, the jurisdiction of the court can be utilized if Iraq requests its support and jurisdiction in handling such crimes. The study concluded that there is an imperative need for an active role of the countries that are experiencing crimes like genocide but are not a member of ICC.

The ICC can exercise jurisdiction over parties for genocide, but it likely cannot do so in connection with the genocide committed by ISIL. There are a limited number of options available, and thus far, none seems realistic. The short-term prediction is that we are not likely to see the international community formally prosecute ISIL and its members any time soon in the ICC. Nonetheless, there is hope that a recent U.N.-initiated investigation might lead to a prosecution by the nation of Iraq. If Iraq does so, the resolution spawning that prosecution "may be looked back on as a major milestone in the 
path toward justice for the countless victims of ISIL in Iraq

\subsection{Recommendations}

1. Iraq shall ratify the Rome Statute of the ICC, in case of non-signature and accession on the basis of Article 12(3) of the Statute of the International Criminal Court, to file a declaration with the registrar to give the prosecutor the right to exercise in the case of the Court. This will ultimately give the ICC jurisdiction over crimes committed by ISIL in Iraq, and will relieve the Iraqi governmental and judicial systems of some of the burden of identifying, detaining and prosecuting ISIL members;

2. The Office of the Prosecutor of the ICC must establish an initial examination into the injustice and inequality of the Yazidi minority in Iraq;

3 . The home state must be able to prosecute members of ISIL for committing crimes genocide in international territory;

4. The Security Council refers the matter to ICC, as it has done in the cases of Darfur by resolution 1593 (2005) and Libya by resolution 1970 (2011). Although a similar resolution referring the Syrian crimes against humanity to the ICC was proposed in 2014 and vetoed by Russia and China, a resolution for ISIL crimes in Iraq should receive less resistance and would, once again, relieve the Iraqi systems of the burden of prosecuting these crimes on such a massive scale.

\section{RESOURCES}

V. Buffon and C. Allison, C. 'The Gendering of Victimhood: Western media and the Sinjar Genocide in Kurdish Studies' [2016] PL175, 196

Cetorelli, V., Sasson, I., Shabila, N., \& Burnham, G. (2017). Mortality and kidnapping estimates for the Yazidi population in the area of mount Sinjar, Iraq, in august 2014: a retrospective household survey. PLoS medicine, 14(5), e1002297.

Ahram, A. I. (2015). Sexual Violence and the Making of ISIS. Survival, 57(3), 57-78.

Nicolaus, P., \& Yuce, S. (2017). Sex-slavery: one aspect of the yezidi genocide. Iran and the Caucasus, 21(2), 196-229.

Ford, S. (2006). Crimes against Humanity at the Extraordinary Chambers in the Courts of Cambodia:Is a Connection with Armed Conflict Required. UCLA Pac. Basin LJ, 24, 125.

A. Jones, Genocide: A Comprehensive Introduction (Routledge 2016) p.57

Marchuk, I. (2015). Fundamental Concept of Crime in International Criminal Law. Springer, ISBN : 9783-642-28245-4
F. R. Chalk, \& K. Jonassohn, (1990) The History and Sociology Of Genocide: Analyses and Case Studies (Yale University Press) p.165

Meierhenrich, J. (2014). Introduction: the study and history of genocide. (Oxford University Press 2014) p.45

Stromseth, J. E. (2011). The International Criminal Court and Justice on the Ground. Ariz. St. LJ, 43, 427.

Dörmann, K. (2003). Elements of war crimes under the Rome Statute of the International Criminal Court: sources and commentary. Cambridge University Press.

Arsanjani, M. H. (1999). The Rome Statute of the international Criminal court. American Journal of International Law, 93(1), 22-43.

Hwang, P. (1998). Defining crimes against humanity in the Rome Statute of the International Criminal Court. Fordham Int'l LJ, 22, 457.

Newton, M. A. (2001). Comparative Complementarity: Domestic Juridiction Consistent with the Rome Statute of the International Criminal Court. Mil. L. Rev., 167, 20.

Albors-Llorens, A. (1998). Changes in the Jurisdiction of the European Court of Justice under the Treaty of Amsterdam. Common Market Law Review, 35(6), 1273-1294.

Van Schaack, B. (2019). National Courts Step Up: Syrian Cases Proceeding in Domestic Courts. Available at SSRN.

Larkin Jr, P. J. (2018). Can Captured ISIS Fighters Be Prosecuted for Genocide in an International Tribunal?.

Roithmaier, K., Tobjasz, M., \& Bove, P. (2020). Year in Review 2018. In Yearbook of International Humanitarian Law, Volume 21 (2018) (pp. 165-260). TMC Asser Press, The Hague.

Kelly, M. J. (2016). Surviving genocide: Lessons from the past and hope for our future.

Bel Trew ,Slave trade: Fleeing Isis militants sell Yazidi captives to fund escape from terror group https://www.independent.co.uk/news/world/middleeast/isis-yazidi-women-slaves-captives-syria-jihadiislamic-state-a8612926.html

Konforta, M., \& Munivrana Vajda, M. (2014). Načelo komplementarnosti u praksi Međunarodnog kaznenog suda. Zagrebačka pravna revija, 3(1), 9-27. Quigley, J. (2016). The genocide convention: An international law analysis. Routledge.

Greco, G. (2007). Victims' rights overview under the ICC legal framework: A jurisprudential analysis. International Criminal Law Review, 7(2-3), 531-547.

Borg Cardona, Y. (2013). A critical analysis of the Rome Statute of the International Criminal Court (Master's thesis, University of Malta).

Scharf, M. P. (1997). Prosecutor v. Tadić. Case No. IT-94-1-T. American Journal of International Law, 718-721. 
Lingaas, C. (2015). Defining the Protected Groups of Genocide through the Case Law of International Courts. International Crimes Database.

Stahn, C., Olásolo, H., \& Gibson, K. (2006). Participation of victims in pre-trial proceedings of the ICC. Journal of International Criminal Justice, 4(2), 219-238.

Clark, R. S. (2001). The mental element in international criminal law: The Rome Statute of the International Criminal Court and the elements of offences. In Criminal Law Forum (Vol. 12, No. 3, p. 291). Springer Science \& Business Media.

Fazel Hawramy, 'Freed Yazidi: I was beaten by Isis because I refused to say the Shahada' (The Guardian 19 January 2015 accessed 16 February 2019
Sebastian Meyer, Corbis, 'A young girl inside a school that's now home to displaced Yezidis.Between The Millstones: The State Of Iraq'S Minorities Since The Fall Of Mosul' (IILHR, MRG, NPWJ and UNPO 2015)

Schmid, A. P. (2015). Challenging the narrative of the Islamic State. The Hague: International Centre for Counter-Terrorism, 1-19.

Sypher, F. (2014). Rape and Sexual Slavery Inside an ISIS Prison. The Daily Beast, 28.

Goldstone, R. J. (2002). Prosecuting rape as a war crime. Case W. Res. J. Int'l L., 34, 277.

Anderson, K. (2016). 'Cubs of the Caliphate': The Systematic Recruitment, Training, and Use of Children in the Islamic State. International Institute for Counter-Terrorism, 1-46.

\section{الآليات الدولية لمقاضاة أعضاء داعش عن جرائم الإبادة الجماعية التي ارتكبوها ضد الإيزيديين في سنجار، العراق-2014 المحكمة الجنائية الدولية (ICC) حالة لدمة الدراسة}

في 3 أغسطس 2014 ، شن تنظيم الدولة الإسلامية الإرهابي في العراق والثام (داعش) ، المعروف أيضًا باسم داعش أو الذي تم اختصاره مؤخرًا إلى الدولة الإسلامية (داعش) ، هجومًا على سنجار في شمال العراق داخل محافظة نينوى. كانت المنطقة موطنًا لنحو 400000 من الإيزيديين، بالإضافة إلى الأقليات الدينية الأخرى، تسبب التنظيم لأكثر من مليولي شخص بالإسية إنتهاكات خطيرة لحقوق الإنسان في محافظة انينوى.

ينص نظام روما الأساسي للمحكمة الجنائية الدولية (ICC) صراحة على أن المكمة تتمتع بالاختصاص القضائي وفقًا لهذا النظام الأساسي فيما يتعلق بجرائم (أ) الإبادة الجماعية ؛ (ب) الجرائم ضد الإنسانية ؛ (ج) جرائم الحرب ؛ (د) جريمة العدوان. تم تفصيلها في المواد 5 والإبادة الجماعية على وجه التحديد في المادة 6.

تمدف هذه الدراسة إلى معرفة ما إذا كان مثل هذه الجرائم الدولية الثنيعة التي ارتكبها تنظيم الدولة الإسلامية ضد الإيزيديين في سنجار بالعراق خلال مكداص هده-2014 يمكن وضعها تحت اختصاص الخكمة الجنائية الدولية وفقًا لوثيقة النظام الأساسي الخاصة بها، نظام روما الأساسي.

الدراسة توضيحية وتستخدم فهج تحليل الححتوى للإجابة عن أسئلة البحث. قام الباحث بتحليل الأدبيات الموجودة وكذلك الوثائق القانونية للمحكمة الجنائية الدولية لتفسير وتحديد اختصاص الحكمة الجنائية الدولية فيما يتعلق بالإبادة الجماعية للإيزيديين في العراق للتوصية والمطالبة بالإصلاح في غهاية الدراسة. الكلمات المفتاحية: الإيزيدية، الذاكرة، الإبادة الجماعية. 